\title{
Technological Interfaces of the Brazilian Naval and Offshore Industry
}

\author{
André Cherubini Alves', Paulo Antônio Zawislak²
}

\begin{abstract}
The recent challenges of the Brazilian naval and offshore industry have generated a unique opportunity for studies on technological innovation and economic development. This paper presents the recent developments and future prospects of this industry under the theoretical framework of 'technological interfaces'. Technological interfaces are defined as the thread of knowledge and technology necessary for establishing a transaction between two or more agents. It is both a theoretical construct and a tool for better understanding industrial coherence and dynamics. The development project of ship and platform construction in Brazil, unveils a potential dynamic similar to large national projects, such as the U.S. space project in the 50 s. By establishing scientific parameters of analysis for the study, it is possible to generate a broader diagnosis of the technological interface matrix of the industry, but mainly it is possible to map the framework of operational gaps and the needs for technical-scientific development.
\end{abstract}

Keywords: technological interfaces; naval and offshore industry; innovation.

Graduate Center on Business Administration. Federal University of Rio Grande do Sul, Brazil. Rua Washington Luiz, 855 Porto Alegre, RS, 90.010-000, Brazil. Phone: + 5551 3308-3536. Fax: + 5551 3308-399I.

E-mail: 'acalves@ea.ufrgs.br (André Cherubini Alves, principal contact for correspondence)

ISSN: 07 I8-2724. (http://www.jotmi.org)

Journal of Technology Management \& Innovation (c) Universidad Alberto Hurtado, Facultad de Economía y Negocios. 


\section{Introduction}

Technology and innovation as the driving forces of industrial organization and dynamics have been present in the literature for more the two centuries now. Recalling the first works of Adam Smith, David Ricardo and Karl Marx in the XVIII and XIX centuries and Joseph Schumpeter, Robert Solow, Richard Nelson and Sidney Winter among many others in the $X X$ century, technological developments and innovation are on the basis of the ongoing changes, revolutions and renewal of the social-economic conditions of nations. Nonetheless, understanding and measuring the mechanism behind the structuring of industries and its economic repercussions have always been a challenge in the academic field.

This has been partially answered by economic traditions from neoclassical orthodoxy to industrial organization approaches like structure-conduct-performance, and transaction costs, as well as evolutionary approaches such as, sectoral, technological or national systems of innovation. However, in spite of their significant contributions, these approaches present partial views either because of the theoretical background and main behavioral suppositions or because of methodological differences that come up due to the type of phenomena each is trying to capture. This paper aims at advancing in this field beginning by posing the following research questions: what determines the shape and scope of an industry and its subsequent dynamics?

If the economic system is based on the flow of transactions among economic agents (producers and consumers), how can one expect an industrial arrangement to take place and how does it change overtime? One general answer is economic "value", that is some firms develop the necessary capabilities for producing something with value in order to sell it to its market (be it another firm or the consumer) (Zawislak, et al, 20l I). If this flow of transactions establishes the links among buyers and sellers or among those economic agents who make and those who buy, what determines who can become the maker and who will be the buyer? In other words, how these agents are organized?

As explained by Williamson (1985), transaction occurs between "technological separate interfaces" (p.l). When seen at the industry level, the firm is only one of the many holders of a particular technological interface transacting among others within full supply chains. Although, in the general sense, production activities or stages from development, extraction of raw materials, supply of inputs, production and delivery of the final outcome of the industry to end consumers follow certain logic, the way these activities are distributed among different firms can take many forms being restricted both technical and economic criteria. In a sense, one could go back to the second question of Coase (1937) "Why is not all production carried on by one big firm?" (p.394).
Technological interfaces, encompassing the various capabilities needed to do things efficiently, are what justify the existence of economic exchange between agents. This means that a transaction is a 'two way street' between agents across whole industries. If on the one hand the buyer transfers the economic medium of value (money), on the other one has the seller transacting technological content that supplies the needs and satisfies the utility of buyers. In this sense, the make-or-buy decision is a typical assessment of organization of the technological interface which happens all the way from the scientific and technological development trough production and sales to end consumers. Therefore, the concept of technological interfaces goes beyond the notion of supply and value chain once it involves the set of economic agents (firms and markets) and also the relevant institutions that influence the development of the industrial arrangement.

In order to develop such construct, this paper analyses the Naval and Offshore Industry in Brazil. The recent developments resulting from economic growth and the prospects for the exploration of oil and gas in the Pre-salt layer have generated a unique opportunity for studies aimed at understanding the dynamics of industrial organization and innovation. The demands directed at domestic companies focused on the development of product and process technologies - both for construction projects of several types and sizes of ships and platforms, and to find technological solutions that do not yet exist - allied to public policies and governmental strategic intentions to encourage production with $70 \%$ of local content, have placed the Brazilian industrial organization in face of a challenge. How to strategically plan and develop a local chain of technological interfaces for production and innovation for Brazilian naval industry? This paper presents the recent developments and future prospects of this industry under the theoretical framework of 'technological interfaces'.

This paper is organized as follows. Section 2 presents a literature review on technological interfaces. Section 3 presents the research method. Section 4 shows some of the discussions possible based the Brazilian Naval and Offshore Industry. Section 5 presents results.

\section{Technological Interfaces}

The need to understand the organization of the industry and its underlying dynamics imposes a challenge in terms of both policy making and management issues. According to Langlois (2003), industrial structure is based on two interrelated but conceptually distinct systems: the technology of production and the organizational structure that directs production. Both systems must solve the problem of economic value, 
that is: how to deliver the most utility at the lowest cost. However, industrial structure has an evolutionary design problem imposed by the ever changing social, economic and technological parameters. In that sense, it is generally accepted in the literature that technology and innovation are key aspects for boosting industrial organization and consequently generating economic development and wealth. Out of this discussion the following research question emerges: what determines the shape and scope of an industry and its subsequent dynamics?

As one explores the economic literature, the answer appears in many and mixed ways' involving economic agents either within the boundaries of the firm or outside of it in the market, as well as involving institutions such as government agents, universities, research centers and even embedded culture that can influence these agents' behavior. If for the orthodox economists, economic agents seek only to maximize utility by finding the best possible resource allocation following a perfect rationality in a perfectly competitive environment with everything else being exogenous, in transaction costs economics and evolutionary approaches the explanation comes in a very different way. It involves bounded rationality, capabilities and technological trajectories.

After all, the essence of industrial organization results from the interplay of technology and economics. Not only technological there is the obvious technical aspect which gives the industry its concrete shape, but also, any industrial arrangement must deal with economic constraints related to its necessary or possible scope. Technology and economics are fundamental axis for industrial organization influencing firms decision to invest in developing internal capabilities or outsourcing specific operations to other firms. Industrial organization is necessarily based on complementarity (Richardson, 1972).

Capabilities-based approach and transaction cost economics offer great potential in explaining the way these two axis play out in configuring industrial activities and its underlying dynamics. In transaction costs economics tradition, the decision to make or buy depends on key dimensions of the transactions between agents such as: asset specificity, uncertainty and frequency (Williamson, 1985). As for neoschumpeterian evolutionary economics, the explanation comes in the ability of firms to develop internal capabilities and routines based on knowledge and skills and change its techno-

'Ronald Coase (1972) once stated that we know very little about the cost of conducting transactions on the market or what the depend on, and are, in fact, appallingly ignorant about the forces which determine the organization of industry" (Coase 1973, p. 64). logical base over time in the process of problem solving and innovation (Nelson and Winter, 1982; Freeman, 1982; Dosi, 1982, Rosenberg, 1983).

These approaches (one way or another) seek to explore what goes on inside of what neoclassical economists would call de "black box", that is the firm. The fact is that the economic organization must deal with both.

It is presumed in this paper that the answer for the above question will arise as we start to deepen the understanding of the concept of 'technological interfaces'. The concept of technological interfaces is very poorly developed in the literature and the notion appeared for the first time in transaction costs economics. Williamson (1985) mentions the technological interfaces as an important part for the vertical integration of economic organization. In his own words "transactions occur when a good or service is transferred across technologically separable interfaces" (p. I), in other words, where a stage of activity ends and another begins. Still, according to Williamson (1985) in an analogy with mechanical systems, "with a well-working interface, as with a well-working machine, these transfers occur smoothly" (p.l). This can happen within or across organizational boundaries. Transaction costs economics poses that the main strategy of firms is to economize by reducing transaction costs (Williamson, 1991) and it aims at explaining the different forms, features and alternative modes of the economic organization (Williamson, 1985). Nonetheless, his unity of analysis is the transaction whereas for evolutionary economics can be found in the firm, its knowledge, routines and capabilities (Alves, et al, 20I I).

If this argument is correct, one can imagine that, in a well working economic system, in order to develop, produce and distribute goods and services with economic value, this will mean necessarily the existence of a chain of technical systems linked through transactions based on complementarities of their technological content. This system is what is composed by a chain of technological interfaces. Technological interfaces are defined as the thread of knowledge and technology necessary for establishing a transaction between two or more agents. In other words, there forms a chain of applied knowledge that justifies the transfer of value through economic transactions from one agent to another.

The development of these technological linkages, therefore, will be adjusted and shaped by the technical-economic restrictions. Moreover, it is imperative in any industry to take into account both technological-scientific constraints and economic constraints which guide the make or buy decision of firms. In this sense, any effort in product innovation, besides being dependent on knowledge acquisition and technological development, is only justified if it fulfills market 
gap of another economic agent. Therefore, the technical and scientific knowledge must meet economic coherence.

Technological interfaces when put together form a thread of applied knowledge (technology) needed to create and put in place the set of operations which allows the smooth flow of a given mix of products (goods or services) across different economic agents. It is restricted to a technical-operational standard of efficiency as well as the consumer's (an individual or a company) value expectation (based on his package of needs). Therefore, the technological interfaces will vary in complexity and economic impact across different sectors.

\section{Technological Interfaces and other approaches to in- dustrial organization}

The concept of technological interfaces has similarities with other approaches such as the notion of the value chain proposed by Porter (1985) or supply chain by Harland (1996). Nonetheless, it involves, besides the purely productive actors (companies), all institutions from science and technology, government and policy makers, to the market. This large set of information can be also compared to national innovation system approach (Freeman 1988; Lundvall 1992; Nelson, 1993) or Technological Systems (Carlsson and Stankiewicz 1991) and Sectoral Innovation Systems (Malerba, 2002). However the concept of technological interfaces tries to fulfill some of the gaps open by each of these approaches as shown in Table 2.

Differently than the approaches above, technological interfaces focuses on the technological content that allows the specific organization of the industry and its dynamics. It seeks to provide a clearer picture of industrial scientific and production chains, their differences regarding technological antecedents, interactions, outcomes and economic value.

Technological interfaces give the outlines of the system, its influences the design and configuration. It builds upon evolutionary economics (Nelson and Winter, 1982) and technological paradigms trajectories (Dosi, 1982) and defines the technological content of the system, that is, the sequence of systematically applied knowledge required to industrial relations with actors performing certain types of specific activities for the development, operation, management and transaction of a particular type of product. The more or less parts of the sequence of applied knowledge the same techno-economic environment, the higher or lower its dynamic potential and wealth generation.

\section{Shape, Scope and Dynamics of Industrial Organization}

Industrial organization arises from the interplay of technology and economics. Technological interfaces provide the technical-economic linkages among and across different economic agents distributed in one or more industries. In a broad sense, technology and economics are the key axis defining shape, scope and dynamics of industrial organization. What then are the fundamental dimensions of industrial organization's shape, scope and dynamics?

We argue that, in order to understand these relationships, two theoretical approaches are complementary: evolutionary and transaction cost economics. Technology defines the technical sequence of industrial activity given the current state of technological domain, established standards and degree of modularity. On the other hand, transaction costs economics explain the adaptive fitness of industrial organization outlining how the different industrial activities will be distributed across firms give their position on asset specificity, transaction frequency and uncertainty which can arise given opportunistic behavior and bounded rationality. While the first follows technical constraints as to what are the activities to take place in order to produce the desired outcome, the second follows economic constraints that guide the make or buy decisions of firms determining when and where such activities will take place.

However, industrial organization's 'design problem' is explained by industrial dynamics. This can only be addressed by adding to the analysis how industrial firms actually introduce new solutions to the market through innovation. While industrial scope distribution result from the condition of asset specificity of firms and their behavioral orientation towards opportunism ${ }^{2}$ and bounded rationality, innovation provides the means through which these conditions change.

The key aspect about innovation is that it alters the condition of asset specificity in the level of the firm and it mitigates bounded rationality opening up new possibilities for the firm to be opportunistic going after profits. However, to be successful in any opportunistic endeavor, the firm must be able to capture value by developing the necessary capabilities in order to provide new solutions to the market and consequently establish new transactions. In fact, in-

\footnotetext{
${ }^{2}$ Within general agency theory and transaction costs, opportunism is generally considered as a potential source of moral hazards from the very nature of principal-agent conflict. However, according to Zawislak (2004), opportunism is an essential part of innovation and competitiveness whenever an individual firm seizes an opportunity naturally looking for profits.
} 


\begin{tabular}{|c|c|}
\hline \multicolumn{2}{|c|}{ Concepts and authors } \\
\hline \multirow{3}{*}{ 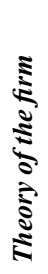 } & Neoclassical economics \\
\hline & (Marshall, Mills) \\
\hline & $\begin{array}{l}\text { Transaction Costs Economics } \\
\text { (Coase, 1937; Williamson, } \\
\text { 1985) }\end{array}$ \\
\hline
\end{tabular}

Structure-Conduct-Performance

(Bain, 1956)

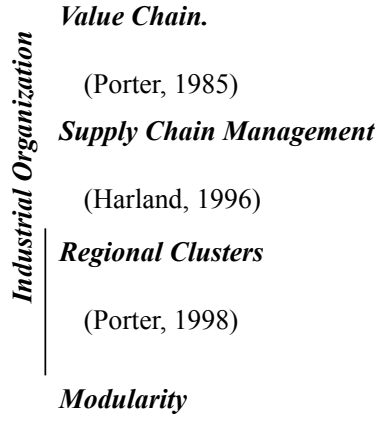

(Baldwin and Clark, 1997)

Technological Paradigms and Trajectories

(Dosi, 1982)

\section{Technological System}

(Carlsson and

Stankiewicz,1991)

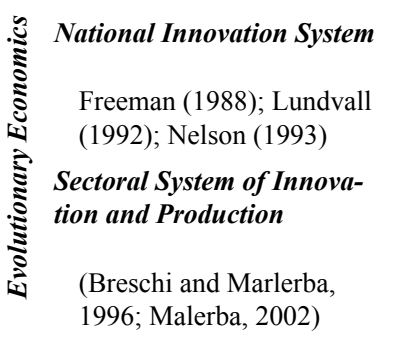

Regional Innovation System

Doloreux and Parto (2005)

Knowledge Networks

Dantas and Bell (2009).
Characteristics and limits of the theory

Technology is an endogenous variable. The firm is seen and production function with a specific technological content (black box) worthless of understanding in detail. The firm is assumed to follow a maximizing behavior with perfect knowledge.

TCE provides a useful explanation of the very existence of firms and industrial organization through the description of hierarchy, hybrid and market modes based on bounded rationality and asset specificities and frequency of transactions. The main goal of the firm is to reduce transaction costs.

SCP draws a critique to the neoclassical presumptions such as the perfect competition, free of barriers mobility of resources and perfect information. The main limitation of both TCE and SCP is their comparative statics approach rather then an evolutionary one.

VC and SCM describe the various processes (such as purchasing, manufacturing, sales and distribution) involved in producing goods and services, starting with raw materials and ending with the delivered product.

Low emphasis is given to the role of technology development.

Identifies geographical concentration of interconnected industries.

Modularity is describes the degree to which a system's components can be separated and re-combined following technical rules, standards and interfaces. It focuses more in analyzing technology constrains, rather than the economic ones.

Draws from the neoschumpeterian approach considering technology as an endogenous phenomenon which is responsible for the interplay between extraordinary breakthroughs (paradigms) and path dependent improvements (trajectories), both subjected to the market selection. It does not goes further in the chain of the industrial organization.

A TS is defined as a dynamic network of agents interacting in a specific economic/industrial area under a particular institutional infrastructure and involved in the generation, diffusion, and utilization of technology. Limitations: It is limited in describing the boundaries of different TS and their determinants.

Very broad concept encompassing all institutions involved in the process of innovation. Difficult to operationalize and measure, specially in a globalized economy.

Describe the structure and boundaries of a sector; the agents and their interactions; the learning, innovation and production processes; the transformation of sectors and the factors at the base of the differential performance of firms and countries in a sector. It does not go further in detail of the interactions among the players within a sector.

Similar to the concept of Cluster. Difficulty in determining the regional boundaries as well as sectoral ones.

It is primarily concerned with the intentionality and decision-making, nature of the technological accumulation activities, the content and direction of knowledge flow and division of labor in knowledge production among actors.
How the technological interfaces differ

Explores the black-box once it deals with the technological content of the firm

Adds the evolutionary approach to the analysis of the industrial organization. The unit of analysis is the technological interface, rather than the transaction.

Adds the evolutionary approach to the analysis of the industrial organization.

Adds a dynamic component describing the different sources of knowledge need for technological development and innovation across different sectors.

It goes beyond the regional analysis encompassing the full chain of technology development and production.

Technological interfaces attempt to understand the interplay between technology and economics.

It attempts to understand the mechanisms behind the flows of knowledge and value among firms within an industrial arrangement.

Seeks to identify the boundaries of technological systems, and how are they determined.

More specific describing all institutions involved to a certain technological interface.

Addresses the relationships among the elements of a sectoral system.

It is more concerned with the technological and more systemic chain contained within and across regions, rather than the region itself.

Besides those it takes into consideration the direction and distribution of the value flow. 
novation is the main way through which firms can economize in transactions costs. Figure 3 illustrates the industrial organization problem.

Technology and economics are the key elements for any industrial arrangement to emerge, evolve and flourish producing economic development and wealth. Identifying the key dimensions behind this dynamic process can allow for a better understanding of the possible technological and economic trajectories of industries, its players, guiding decision and policy makers. Institutions are on the background of this whole system once "getting them right" can create economic incentives influencing both shape and scope of the industrial activities within national and international borders.

\section{Method of Investigation}

This is a theoretical paper presenting the first literature review on the concept of technological interfaces and organizes a case study based in the in re-emerging $\mathrm{Naval}$ and Offshore Industry in Brazil which is facing several challenges in science, technology and in its very industrial organization. This industry offers an opportunity for studying the benefits of technological innovation and its impact on the national economy as a whole.

This study is part of a three-year research project in the sector. In this sense, the paper organized a literature review on industrial organization approaches to build the argu-

\section{INDUSTRIAL ORGANIZATION}

TECHNOLOGY DELINIATES INDUSTRIAL ORGANIZATION'S SHAPE
ECONOMICS (TCE)

OUTLINES THE DISTRIBUITION OF INDUSTRIAL ACTIVITIES ACROSS FIRMS

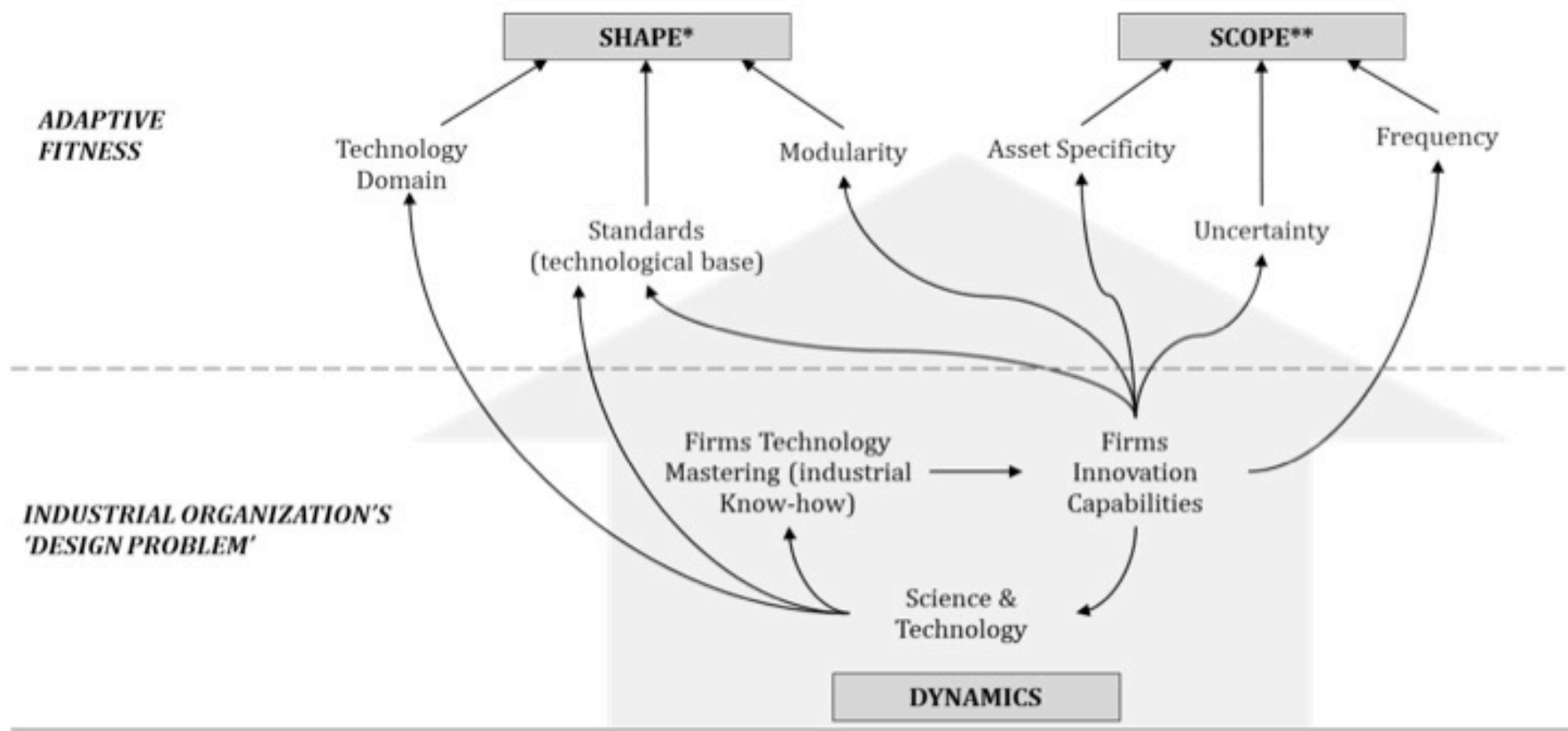

${ }^{*}$ By SHAPE it is meant, the Technical-Sequence

** By SCOPE, the distribuition of industrial activities

Figure I. Shape, Scope and Dynamics of Industrial Organization

\begin{tabular}{|l|l|l|}
\hline Phases & Data collection & Sources of Information \\
\hline Theoretical construction and refinement & $\begin{array}{l}\text { Literature Review and } \\
\text { Exploratory Research }\end{array}$ & Academic on industrial organization \\
\hline Exploratory (Immersion in the industry) & Literature review & $\begin{array}{l}\text { Secondary data:Thesis, Dissertations, loca } \\
\text { reports from sector entities. }\end{array}$ \\
\hline
\end{tabular}

Table I - Research Phases

ISSN: 07I 8-2724. (http://www.jotmi.org) 
ment around the need for a different approach using the concept of technological interfaces. To accomplish this goal, this work was divided in two mains phases as summarized in Table I. In the first phase, there is theoretical review and proposal of general analytical framework for understanding the concept of technological interfaces.Then, an exploratory literature review produced an overview of the recent technological and economic challenges of the naval and offshore industry in Brazil.

In the next section, we discuss some of these issues in the re-emerging Naval and Offshore industry in Brazil.

\section{Technological Interfaces in the Brazilian Naval and Offshore Industry}

The Naval and Offshore industry is a complex array of institutions and firms specializing in different sectors, encompassing several shipyards and suppliers of products and services, such as engineering design, ship parts and metallurgical technology. In the specific case of Brazil, this giant sector is arising to supply both technologies and equipment to allow Oil and Gas Exploration and Production (E\&P) of the Pre-
Salt reserves found in 2006. Because of this recent scenario the naval industry assumes even greater proportions and specificity. This is because it involves, besides the construction of ships and platforms, the construction of drilling rigs and oil wells producing units that involve a high level of scientific and technological knowledge in various specialized areas, such as: physical-chemical, geological and engineering. According to ONIP (20I I), key chain processes and activities offshore can be seen in Figure 2.

Nonetheless, in order to allow this enormous operation to happen, certain conditions of technology development, equipment and know-how must be met. This goes all the way from seismic technologies for geological mapping of possible drilling fields, to the drilling itself, exploration, production and transportation of the crude oil to its end stages.

Therefore, this current scenario puts Brazilian shipbuilding and Offshore industry facing challenges that range from the scale of production needed to technological development and innovation. Favarin (2008) describes some of the strategies to stimulate the naval supply chain can have two origins: the market reserve (with the imposition of trade barriers

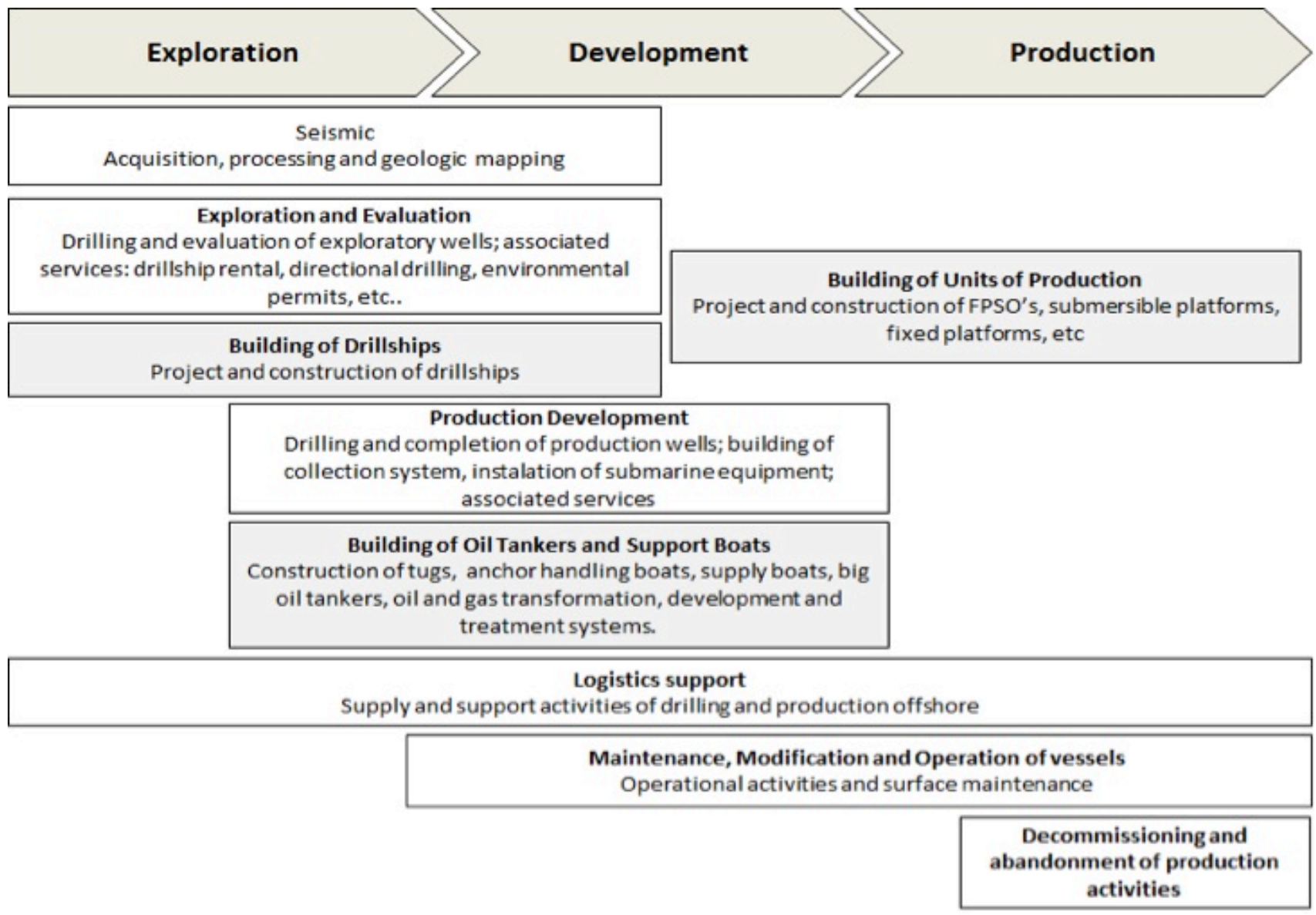

Figure 2. Situating the Naval and Offshore Industry within Oil Exploration and Production activities. Source:Adapted from ONIP (20II)

ISSN: 07 I8-2724. (http://www.jotmi.org)

Journal of Technology Management \& Innovation (c) Universidad Alberto Hurtado, Facultad de Economía y Negocios. 
of foreign capital and fiscal benefits to local companies), or from the development of local industry (creating incentives for firms to produce according to international standards).

Moreover, the estimated demands for offshore platforms and ships by 2020, already offer some positive outlook for the industry. According to ONIP (20l I), the projection for 2020 is to be produced 62 drilling units between drillships and fixed platforms, 68 production units (FPSO's, platforms submersibles and fixed), 74 tankers (Suezmax, Aframax, Panamas among others), and 235 support boats (tugs, anchor handling boats, logistical support, etc.).

Figure 3, briefly illustrates some of the key aspects of such a chain of technological interfaces from the basic inputs, going shipping parts, systems, shipyards and to deliver the final output such as: platforms, tankers, support boats, drillships and production units. PETROBRAS is the Brazilian public company which is the main actor in exploring the Pre-Salt layer.This company, supported by governmental incentives is responsible for leading the largest part of orders of several types of ships and platforms. As it has been discussed previously, the Brazilian government has set public policy in order to create incentives for national firms to initiate a process of technological catch-up.

Several research efforts have been conducted in the field to point the main gaps and opportunities for domestic industry in this sector. According to Oliveira (2009), a major weakness of Brazilian companies is the lowest capacity and technological innovation, where most companies are international licensing of technology, when the firm is not a subsidiary of a multinational company. Domestic enterprises occupy the lower segments of basic engineering and technological complexity ends up being left to international companies. Even in sectors considered important to the aggregate value of ship building as is the sector of ship parts and systems, international experiences show that occurs much investment in R\&D laboratories and focused on specific shipbuilding (DE NEGRI, 20II).

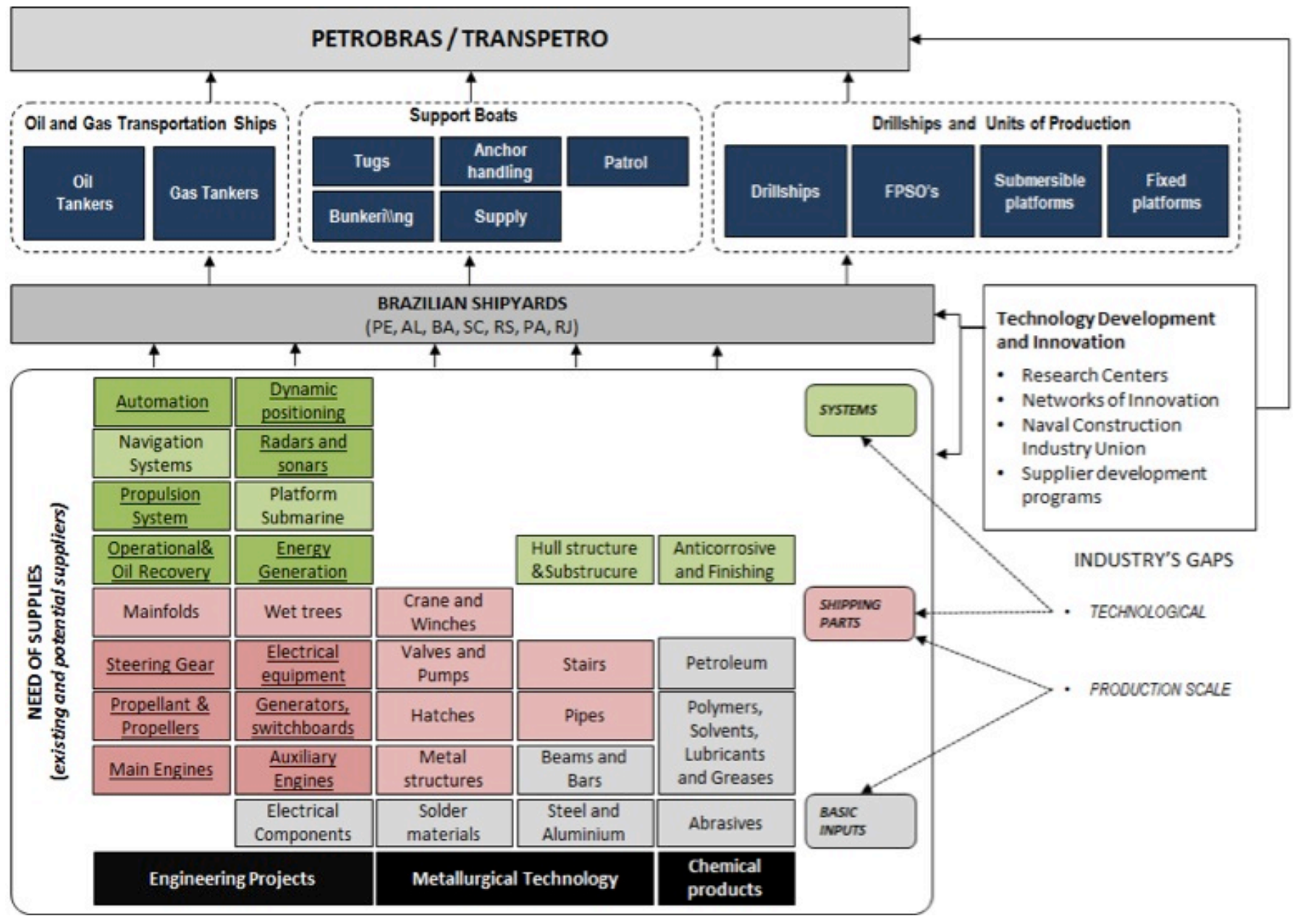

Figure 3. Overlook on the Brazilian Naval and Offshore Industry and main challenges.

ISSN: 07 I8-2724. (http://www.jotmi.org)

Journal of Technology Management \& Innovation (c) Universidad Alberto Hurtado, Facultad de Economía y Negocios. 
Among some of the challenges is the ability of companies to achieve sufficient scale to deliver products that meet technical quality standards and competitive prices. As National Organization of the Petroleum Industry (ONIP, 20II), the biggest challenge at the moment concerns the gaps competitiveness of supply of goods and services. One of the signs of low competitiveness can be realized by the low presence or absence of qualified local companies for the supply of certain groups of goods and services, lists of suppliers operating companies. The ONIP produced a record of national companies that meet the necessary requirements for suppliers to this sector. In twelve years, membership has nearly two thousand five hundred companies, this list still needs to be expanded.

As a matter of fact, Brazil has a reasonable production of raw-materials (basic inputs) and the first stages of transformation. On the other hand, as the complexity of the technology increases, Brazil lacks competitiveness and pro- duction capacity represented in figure 3 , by the underlined boxes both in ship-parts and systems. This happens either by the lack of technological know-how or economic feasibility corresponding to higher costs of production.

According to Oliveira (2008), the challenge of a sector policy is to surpass the scope of the model of import substitution, which until now was not able to form a truly competitive Oil Industry (IPP). Therefore, it is necessary to clearly define the focus of action for the development of an industrial and technological policy. That is, it is necessary to go beyond the simple occupation of the internal market for local manufacturing, but to prioritize the development of endogenous technological content to create a competitive advantage.

Shipyards themselves are also a main concern. In order to be able to accelerate de process of technological transfer, many shipyards in Brazil are looking for international partners. Figure 4 shows the special distribution of these ship-

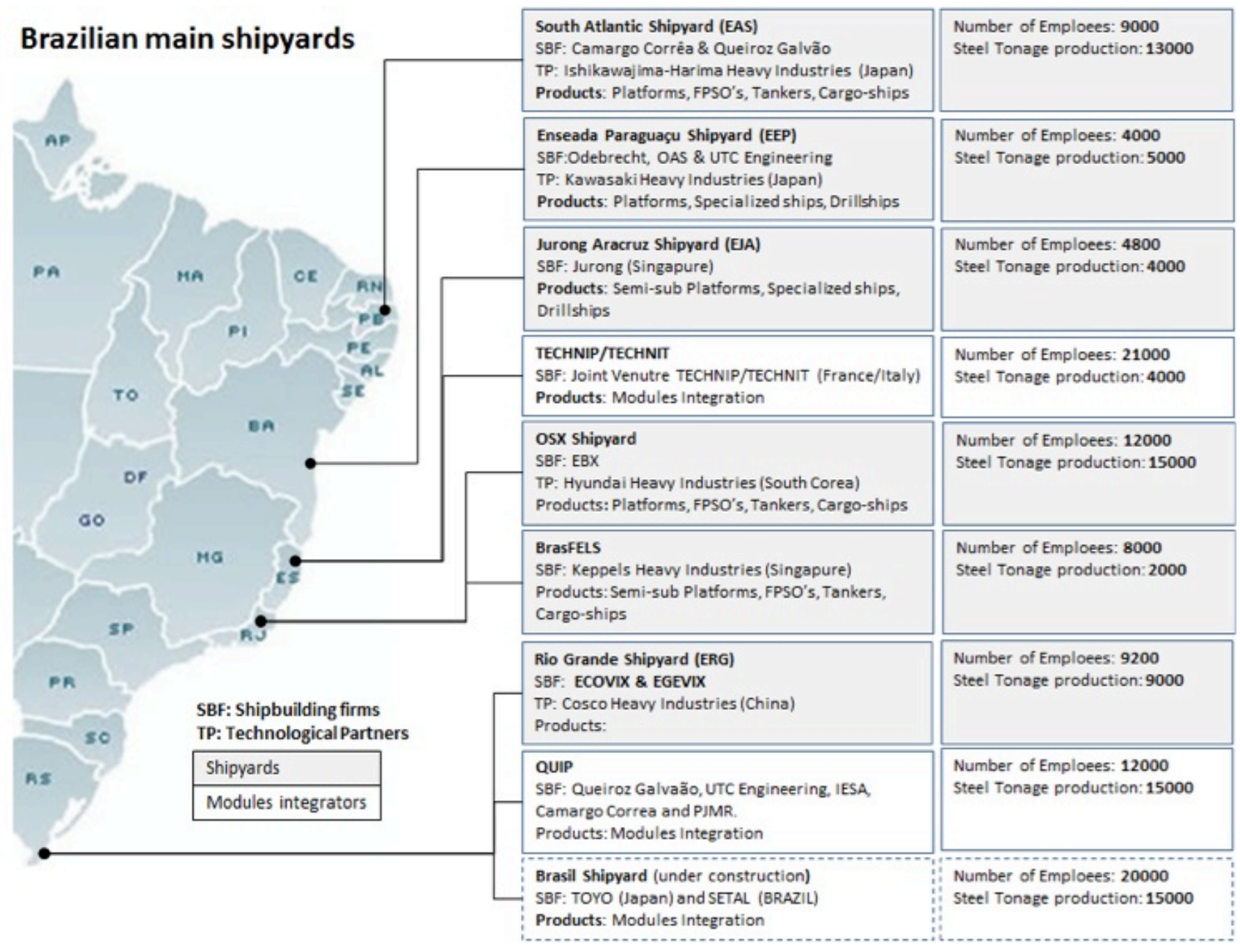

Figure 4. Brazilian main Shipyards

ISSN: 07I 8-2724. (http://www.jotmi.org)

Journal of Technology Management \& Innovation (c) Universidad Alberto Hurtado, Facultad de Economía y Negocios. 
yards in Brazil and a description of types of products and their technological partners. The shipyards are classified in three different types: i) "large scale shipyards" which builds vessels larger than $500.000 \mathrm{~m}^{2}$; ii) "medium scale shipyards" which builds smaller vessels like cargo ships, gas tankers and oil tanker; iii) "small scale shipyards" that builds boats and support vessels.

There are six large scale shipyards in Brazilian Offshore Industry that are spread through the country. Besides that, there are also three "module integrators" where the hoofs are coupled with the modules. In the map bellow it is visible the locations of which one of these yards. Technological partners come from Japan, South Korea, China, and Singapure with different purposes but all of them carrying special technological know-how. Brazilian shipbuilding companies are almost all being built from scratch combining local capabilities on industrial construction or building construction.

On the next section there will be discussed some of the theoretical implications and public implications.

\section{Discussion and Policy Implications}

According to specialists in the sector, the development project of shipbuilding and platforms for Offshore Oil Exploration and Production in Brazil unveils a potential dynamic similar to large national projects, such as the U.S. space project in the 50 s. Governmental strategic intentions are trying to create the necessary stimulus conditions for the industry to establish itself. But the path is long and not easy.

Policies can help create the necessary incentive mechanisms for firms, however they are not sufficient to ensure such a giant endeavor to take place nor to be sustainable of in the long run. It is necessary that the sector companies expand their repertoire of skills to generate real competitive advantages that remain after the absence of incentive mechanisms. In this sense, beyond the market reserve, policy must anticipate and plan to replace this mechanism of stimulation through the appropriation of knowledge and skills on the part of firms.

Nonetheless, many questions remain and the establishing of a strategic plan to build such technological development and operational capabilities from scratch is not a consensus nor clear among actors. Neoclassical economics would suggest that technology is exogenous and available to anyone who wants to acquire it. If decision and policy makers take this too seriously, it may lead to potentially disastrous outcomes. Technological and operational learning is a hard thing to do. Public policy makers and firms' decision makers need to be able to match the technological alternatives there are in the industry with firms or national local levels of capabilities and plan its way up.
There are many questions whether or not the Brazilian industry will be able to overcome some of the technological and economic challenges. There is the skepticism of some related to the real capacity of the country to overcome its technological lag in certain areas. Other question that remains is the capacity of the Brazilian industry to catch-up and at the same time achieves worldwide competitiveness in terms of quality, price and delivery time.

Nelson (1993) points out that it is neither sufficient nor adequate for the government to decide which industries to give incentives based on high-technology criteria or intention. Nations should try to focus in areas where the intention meets its technology stage and countries vocational areas. In this sense, certain complex high-tech industries in order to be successfully implemented, must respect the current nation's state of knowledge and technological development in the specific areas required as well as its capacity of absorbing new technologies and learning. Otherwise, it runs the serious risk of failure. In other words, it is necessary to acquire or develop and domain the need technological interfaces in order go beyond and innovate.

Bringing this discussion to the Brazilian example of Naval and Offshore Industry just being created, one could ask: why is the government trying to develop such industry while there are known higher-qualified producers in Japan, Korea, Singapore, and China? There are a couple of reasons. The most generic one is the argument related to the overall perspectives of stimulating the economy and creating jobs well as the favorable opportunity for economic development through the organization of a full industry and technological innovation. But a more specific reason seems to be timing. This enters as an economic variable. While, the Brazilian oil and gas industry announces a new discovery of reserves every year, the demand for platforms and vessels increases in a higher rate than the worldwide production capacity. This leads to order books filled and wait lines of four years in some cases. This opens up a window of opportunity for the Brazilian industry to prepare and catch up. Nonetheless, it needs to move fast, as well as governmental legislation in the area.

Among the main challenges cited by specialists are the discontinuity of the demand caused by bad industrial performance, high costs not only regarding labor but also high taxation, low labor qualification and governmental mistakes in evaluating the current scenario and choices for public policy. Another challenge is related to the industrial competitiveness of local firms. Brazil has a strong base industry to provide the basic inputs to the naval industry. However it still needs to acquire technological competences to deal with more complex shipping parts and systems. Besides technology, firms must also develop managerial competences to 
deal with a market highly based in contractual relations and complex number of suppliers.

This paper argues that, it is necessary to establish scientific parameters of analysis for the study of industrial organization which companies technology and economics. By doing so, it is possible to generate a broader diagnosis of how activities are or should be distributed among firms based on clear parameters of the necessary capabilities and expected performance. The chain of technological interface is the set of technological-content need to produce the desired outcome. As a practical tool, such an analysis may provide framework for understanding operational gaps and industrial coherence from technical-scientific development to production which could be expanded to others industries.

\section{Conclusions}

All this challenges are related to both, the industrial technological base as well as to economic characteristics and possibilities. These characteristics provide the choice possibilities for decision makers to decide in what areas to invest. By recalling Coase's question "Why is not all production carried on by one big firm?" and the "hint" provided by Williamson (1985), technological interfaces, may be a possible path for answering how industries evolve and get their shape. Like a moving puzzle where each piece must encounter its counterpart but it may change overtime because of technological innovation or economic restrictions, technological interfaces provide means for understanding industrial organizational and dynamics.

How these interfaces will play out will depend on number of technical and economic circumstances. The technological interfaces are a techno-social-economic construct for understanding national, regional and sectoral characteristics involving $(I)$ the recognition and understanding of the existing network of support institutions for scientific and technological development for specific industries, (2) level of utilization of the existing industry's technical-operational structure, and (3) socioeconomic wealth generation through the development of knowledge and skills for technological innovation. Technological Interfaces is, therefore, a theoretical construct and, at the same time, a tool in order to understand the paths for establishing a greater coherence to the dynamic set of relationships between scientific and technological activities, industrial-production and innovation. It is a fundamental element behind shape, scope and dynamics of industrial organization.

\section{Acknowledgements}

The present study was carried out with the financial support from the Brazilian National Council for Scientific and Technological Development (CNPq).

\section{References}

ALVES, A, C., Zen, A, C., Padula, A. D. (20I I). Routines, Capabilities and Innovation in the Brazilian Wine Industry. Journal of Technology Management and Innovation 6 (2), I28-I44. doi: http://dx.doi.org/I0.4067/S07 I8-272420I I 000200009

BAIN, Joe S. (1956). Barriers to New Competition: Their Character and Consequences in Manufacturing Industries, Harvard University Press.

BALDWIN, C.Y, Clark, K. B. (1997). Managing in the Age of Modularity. Harvard Business Review, Sept/Oct, pp.8I-93.

BRESCHI, S. and F. Malerba (1996), 'Sectoral Systems of Innovation,' in C Edquist (ed.), Systems of Innovation. Pinter London.

CARLSSON, B. and Stankiewicz, R. (199I). On the nature, function and composition of technological systems. Journal of Evolutionary Economics. (I), 93-I I8. DOI: http://dx.doi. org//0.1007/bfOI2249/5

COASE, R. (1937). The nature of the firm. Economica, 4 (16), 386-405.

COASE, R. H. (1972). Industrial organization:A proposal for research.V.R. Fuchs (Ed.), Policy issues and research opportunities in industrial organization, National Bureau of Economic Research, New York.

DANTAS, E. Bell, M. (2009). Latecomer firms and the emergence and development of knowledge networks: The case of PETROBRAS in Brazil Research Policy (38) 829-844. DOI: http://dx.doi.org//0.1016/j.respol.2009.01.007

DE NEGRI, João Alberto et al. (20I I) Poder de compra da Petrobrás: impactos econômicos nos seus fornecedores síntese e conclusões. Brasília: IPEA.

DOLOREUX, D; Parto, S. (2005). Regional innovation systems: Current discourse and unresolved issues, Technology in Society, (27) I33-153.

DOSI, G. (1982). Technological paradigms and technological trajectories. Research Policy, I I: I47-162. DOI: http://dx.doi. org/I0.1016/0048-7333(82)90016-6 
FAVARIN, J. et al. (2008). Estratégias para a navipeças brasileira. In: Centro de Estudos e Gestão Naval. Available at $<$ www.gestaonaval.org.br/...\%20Navipeças/> Accessed in Dec, I7th, 2010.

FREEMAN, C. (1987). Technology Policy and Economic Performance: Lessons from Japan, London: Pinter.

HARLAND, C. (1996). Supply Chain Management: Relationships, Chains and Networks. British Journal of Management, Special Issue, (7) 63 - 80. DOI: http://dx.doi. org/I0.1 III/j. I467-855I.1996.tb00I48.x

KNIGHT, F.H, (192I). Risk, Uncertainty and Profit (New York: Harper).

LANGLOIS, R., and Robertson, P. (1992). Networks and innovation in a modular system: Lessons from the microcomputer and stereo component industries. Research Policy, (2I), 297-13. http://dx.doi.org//0.1016/0048-7333(92)90030-8

LANGLOIS, R, N; Robertson, P. L. (1995) Firms, Markets, and Economic Change: A Dynamic Theory of Business Institutions . London: Routledge.

LANGLOIS, R.N. (2003). The Vanishing Hand:The Changing Dynamics of Industrial Capitalism. Industrial and Corporate Change, 12 (2), 35I-385. DOI: http://dx.doi.org//0.2139/ ssrn. 285972

LUNDVALL, B-Å. (ed.) (1992). National Systems of Innovation: Towards a Theory of Innovation and Interactive Learning, London: Pinter Publishers.

MALERBA, F. (2002). Sectoral systems of innovation and production. Research Policy (3I) 247-264. DOI: http://dx.doi. org/I0.1016/s0048-7333(0I)00139-I

METCALFE, J.S., (1995). Technology systems and technology policy in an evolutionary framework. Cambridge Journal of Economics (19), 25-46.

NELSON, R.,Winter, S. (1982). An Evolutionary Theory of Economic Change. The Belknap Press of Harvard University Press, Cambridge, Ma.

NELSON, R. and Rosenberg, N. (1993). Technical innovation and national systems. In: Nelson, R. (ed). National innovation systems: a comparative analysis. New York, Oxford: Oxford University.
OLIVEIRA, A. (2009). Indústria Para-Petrolifera Brasileira Competitividade: Desafios e Oportunidades. Rio de Janeiro. Available at: http://www.ie.ufrj.br/datacenterie/pdfs/seminarios/pesquisa/textol8I I.pdf.Accessed in Dec, 17th, 2010.

ONIP (201I). Oportunidades e Desafios da Agenda de Competitividade para Construção de uma Política Industrial na Área de Petróleo: Propostas para um Novo Ciclo de Desenvolvimento Industrial.

PORTER, M.E. (1985). Competitive Advantage, Free Press, New York.

PORTER, M.E (1998). Clusters and the new economics of competition. Harvard Business Review, 76 (6), 77-90.

RICHARDSON, George B. (1972). The Economic Institutions of Capitalism. Economic Journal, v. 82(327), 883-896.

ROSENBERG, N. (1983). Inside the Black Box: Technology and Economics. Cambridge University Press: Cambridge.

WILLIAMSON, O. E. (1985). The Economic Institutions of Capitalism. The Free Press: New York.

WILLIAMSON, (1991). "Strategizing, Economizing, and Economic Organization". Strategic Management Journal 12 (special issue). DOI: 10.1002/smj.4250I21007

ZAWISLAK, P.A. (2004). "From the 'Dream of Opportunities' to the 'Nirvana of Trust': issues for a framework on cooperative agreement stability". READ, Porto Alegre, 34(6).

ZAWISLAK, P. A; Alves, A. C.; Tello-Gamarra, J.; Barbeux, D.; Reichert, F. M. (20I2) Innovation Capability: From Technology Development to Transaction Capability. Journal of Technology Management \& Innovation.Volume 7, Issue 2. p. 14-27. DOI: http://dx.doi.org/I0.4067/S07 I8-272420I 2000200002 